ISSN 0258-7122 (Print), 2408-8293 (Online)

Bangladesh J. Agril. Res. 41(2): 345-352, June 2016

\title{
EFFECT OF FERTILIZER ON CORIANDER SEED PRODUCTION
}

\author{
M. M. KAMROZZAMAN ${ }^{1}$, S. AHMED ${ }^{2}$ AND A. F. M. R. QUDDUS ${ }^{3}$
}

\begin{abstract}
A field experiment on coriander (Coriandrum sativum L.) was carried out during rabi seasons of 2011-12 and 2012-13 in Low Ganges River Flood Plain Soil under AEZ-12 at Farming System Research and Development Site, Hatgobindapur, Faridpur to find out optimum and economic doses of fertilizers for coriander (var. BARI Dhania 1) for sustainable higher yield and to update balanced fertilizer recommendation for target yield. The experiment was laid out in a randomized complete block design with 8 treatments viz. $\mathrm{T}_{1}=\mathrm{N}_{118} \mathrm{P}_{47} \mathrm{~K}_{26} \mathrm{~S}_{10} \mathrm{Zn}_{2.2} \mathrm{~B}_{0.8} \quad \mathrm{Kgha}^{-1}, \quad \mathrm{~T}_{2}=\mathrm{N}_{147} \mathrm{P}_{47} \mathrm{~K}_{26} \mathrm{~S}_{10} \mathrm{Zn}_{2.2} \mathrm{~B}_{0.8} \mathrm{Kg}$ ha $^{-1}, \mathrm{~T}_{3}=$ $\mathrm{N}_{147} \mathrm{P}_{59} \mathrm{~K}_{26} \mathrm{~S}_{10} \mathrm{Zn}_{2.2} \mathrm{~B}_{0.8} \quad \mathrm{Kg} \quad \mathrm{ha}^{-1}, \quad \mathrm{~T}_{4}=\mathrm{N}_{147} \mathrm{P}_{47} \mathrm{~K}_{32} \mathrm{~S}_{10} \mathrm{Zn}_{2.2} \mathrm{~B}_{0.8} \quad \mathrm{Kgha}^{-1}, \quad \mathrm{~T}_{5}=$ $\mathrm{N}_{118} \mathrm{P}_{59} \mathrm{~K}_{32} \mathrm{~S}_{10} \mathrm{Zn}_{2.2} \mathrm{~B}_{0.8} \quad \mathrm{Kgha}^{-1}, \quad \mathrm{~T}_{6}=\mathrm{N}_{147} \mathrm{P}_{59} \mathrm{~K}_{32} \mathrm{~S}_{10} \mathrm{Zn}_{2.2} \mathrm{~B}_{0.8} \quad \mathrm{Kgha}^{-1}, \quad \mathrm{~T}_{7}=$ $\mathrm{N}_{88} \mathrm{P}_{35} \mathrm{~K}_{19} \mathrm{~S}_{8} \mathrm{Zn}_{1.6} \mathrm{~B}_{0.6} \mathrm{Kgha}^{-1}$ and $\mathrm{T}_{8}=$ Native nutrient (Control). The highest seed yield (1373 $\mathrm{kg} \mathrm{ha}^{-1}$ ) was obtained from the treatment $\mathrm{T}_{3}$ which was statistically similar with $\mathrm{T}_{1}, \mathrm{~T}_{2}, \mathrm{~T}_{3}, \mathrm{~T}_{4}, \mathrm{~T}_{5}$ and $\mathrm{T}_{6}$ treatments. The soil test based treatment $\mathrm{T}_{1}$ produced $1311 \mathrm{~kg}$ yield $\mathrm{ha}^{-1}$ and yield difference of ther added fertilizer treatment with $\mathrm{T}_{1}$ was only $5 \%$. The fertilizer added treatments didn't exert the significant difference with soil based treatment $\left(\mathrm{T}_{1}\right)$ on yield and yield contributing characters. However, $\mathrm{T}_{1}$ treatment appeared to be the best suited combination because of its higher gross margin Tk 41,769 ha- ${ }^{-1}$, capability in reducing nutrient cost $\mathrm{Tk} 13106 \mathrm{ha}^{-1}$ and the highest marginal rate of return (MRR) $(108 \%)$ whereas treatment $\mathrm{T}_{3}$ covered $21 \%$ MRR and the highest nutrient cost among the treatments and hence treatment, $\mathrm{N}_{118} \mathrm{P}_{47} \mathrm{~K}_{26} \mathrm{~S}_{10} \mathrm{Zn}_{2.2} \mathrm{~B}_{0.8}$ $\mathrm{Kg} \mathrm{ha}^{-1}$ (100\% NPKSZnB from STB dose) may be recommended for coriander seed production in the study area.
\end{abstract}

\section{Introduction}

Coriander (Coriandrum sativum L.) is one of the important spices in Bangladesh. Seeds of the crops are used as spice, while its tender green leaves are used as culinary herbs. In Bangladesh, the average area of coriander is around 0.33 lakh hectares of land and production 0.38 lakh metric tons in 2013-14 (DAE, 2015). Faridpur district stands first in terms of area (2573 ha) and production (2433 tons) among other districts of Bangladesh. Bangladesh imported coriander seed about 93 tons expending 3000 US dollar in 2006 and 190 tons in 2008-09 (Anon., 2011). The average yield $\left(825 \mathrm{~kg} \mathrm{ha}^{-1}\right)$ of coriander is low whereas the research yield is 1.5 tha $^{-1}$ (SAARC Ag. centre, 2006). One of the most important reasons for low yield is the application of imbalanced and improper fertilization. Fertilizer is the vital input that plays a significant role in exploring the highest

${ }^{1}$ Principal Scientific Officer, ${ }^{2}$ Senior Scientific Officer, ${ }^{3}$ Scientific Officer, On-Farm Research Division, Bangladesh Agricultural Research Institute (BARI), Faridpur, Bangladesh. 
yielding capacity of any crop. The requirement of fertilizer for any crop varies with the cultivars and soil types in agro-ecological zones (Mitra et al., 1990). An adequate supply of plant nutrients is required in order to ensure proper development and potential yield for a particular crop. Judicious application of fertilizer has positive impact on growth and yield of crop. In order to obtain satisfactory results the nutrients should be applied in optimum dose. It was reported that the application of macronutrients (NPKS) markedly increased yield of coriander seed (Anon., 2008). Among different major plant nutrients, nitrogen is required in large amounts by plants because it is a constituent of macromolecules such as protein, encourages cell elongation and vegetative growth. The coriander absorbs most of phosphorous in early growth stages and increases seed yield (Gosh et al, 1986). Potassium is responsible for chlorophyll formation which plays an important part in the strength of cells and encourages flower and fruit formation. Tripathi et al., (2009) reported that the seed yield increases with the application of sulphur and potassium. In Bangladesh, soil nutrient is diminishing day by day due to intensive cropping and the soil $\mathrm{C}$ and $\mathrm{N}$ status in Bangladesh has decreased considerably (Ali et al., 1997). A judicial application of fertilizer must be followed for reducing soil nutrient. Research information regarding the suitable dose of NPKSZnB for the satisfactory production of coriander in Bangladesh is very meagre although some fertilizer based research has accomplished by scientists of BARI. Considering the above facts, the present study was undertaken to assess the appropriate combination of $\mathrm{N}, \mathrm{P}, \mathrm{K}, \mathrm{S}, \mathrm{Zn}$ and B for obtaining satisfactory yield of coriander seed in AEZ12 and also to evaluate the economic return of coriander.

\section{Materials and Method}

The study was conducted at Farming System Research and Development Site, Hatgobindapur, Sadar Faridpur during rabi season of 2011-12 and 2012-13. Soil samples were collected from the experimental fields from a depth of 0-15 cm prior to application of fertilizers in both the years. Results of soil analysis are presented in Table 1. The soil of experimental field was clay to clay loam and slightly alkaline in nature. The average soil nutrient level of $\mathrm{N}$ and $\mathrm{P}$ was very low, $\mathrm{K}$ and $\mathrm{S}$ was medium and $\mathrm{Zn} \& \mathrm{~B}$ was low (Table 1 ).

The experiment was set up in a randomized complete block design with six dispersed replications. The recommended fertilizer dose for coriander was computed on average data of soil test base (STB) value for high yield goal.There were eight treatments viz., $\mathrm{T}_{1}=100 \% \operatorname{NPKSZnB}(\mathrm{STB}), \mathrm{T}_{2}=\mathrm{T}_{1}+25 \% \mathrm{~N}, \mathrm{~T}_{3}=$ $\mathrm{T}_{1}+25 \% \mathrm{NP}, \mathrm{T}_{4}=\mathrm{T}_{1}+25 \% \mathrm{NK}, \mathrm{T}_{5}=\mathrm{T}_{1}+25 \% \mathrm{PK}, \mathrm{T}_{6}=\mathrm{T}_{1}+25 \% \mathrm{NPK}, \mathrm{T}_{7}=$ $75 \%$ of $\mathrm{T}_{1}$ and $\mathrm{T}_{8}=$ Native nutrient (Control). The treatments with full amounts of nutrients were shown in below:

$$
\begin{aligned}
& \mathrm{T}_{1}=\mathrm{N}_{118} \mathrm{P}_{47} \mathrm{~K}_{26} \mathrm{~S}_{10} \mathrm{Zn}_{2.2} \mathrm{~B}_{0.8} \mathrm{Kg} \mathrm{ha}^{-1} \\
& \mathrm{~T}_{2}=\mathrm{N}_{147} \mathrm{P}_{47} \mathrm{~K}_{26} \mathrm{~S}_{10} \mathrm{Zn}_{2.2} \mathrm{~B}_{0.8} \mathrm{Kg} \mathrm{ha}^{-1}
\end{aligned}
$$




$$
\begin{aligned}
& \mathrm{T}_{3}=\mathrm{N}_{147} \mathrm{P}_{59} \mathrm{~K}_{26} \mathrm{~S}_{10} \mathrm{Zn}_{2.2} \mathrm{~B}_{0.8} \mathrm{Kg} \mathrm{ha}^{-1} \\
& \mathrm{~T}_{4}=\mathrm{N}_{147} \mathrm{P}_{47} \mathrm{~K}_{32} \mathrm{~S}_{10} \mathrm{Zn}_{2.2} \mathrm{~B}_{0.8} \mathrm{Kg} \mathrm{ha}^{-1} \\
& \mathrm{~T}_{5}=\mathrm{N}_{118} \mathrm{P}_{59} \mathrm{~K}_{32} \mathrm{~S}_{10} \mathrm{Zn}_{2.2} \mathrm{~B}_{0.8} \mathrm{Kg} \mathrm{ha}^{-1} \\
& \mathrm{~T}_{6}=\mathrm{N}_{147} \mathrm{P}_{59} \mathrm{~K}_{32} \mathrm{~S}_{10} \mathrm{Zn}_{2.2} \mathrm{~B}_{0.8} \mathrm{Kg} \mathrm{ha}^{-1} \\
& \mathrm{~T}_{7}=\mathrm{N}_{88} \mathrm{P}_{35} \mathrm{~K}_{19} \mathrm{~S}_{8} \mathrm{Zn}_{1.6} \mathrm{~B}_{0.6} \mathrm{Kg} \mathrm{ha}^{-1} \\
& \mathrm{~T}_{8}=\text { Native nutrient (Control) }
\end{aligned}
$$

\begin{tabular}{|c|c|c|c|c|c|c|c|c|c|}
\hline & Texture & $\mathrm{pH}$ & $\begin{array}{l}\mathrm{OM} \\
(\%)\end{array}$ & $\begin{array}{c}\text { Total } \\
\mathrm{N} \\
(\%)\end{array}$ & $\begin{array}{c}\text { Available } \\
\text { P } \\
(\mu \mathrm{g} / \mathrm{g} \\
\text { soil })\end{array}$ & $\begin{array}{c}\mathrm{K} \\
\text { (meq/ } \\
100 \mathrm{~g} \\
\text { soil) }\end{array}$ & $\begin{array}{c}\mathrm{S} \\
(\mu \mathrm{g} / \mathrm{g} \\
\text { soil })\end{array}$ & $\begin{array}{c}\mathrm{Zn} \\
(\mu \mathrm{g} / \mathrm{g} \\
\text { soil) }\end{array}$ & $\begin{array}{c}\text { B } \\
(\mu \mathrm{g} / \mathrm{g} \\
\text { soil })\end{array}$ \\
\hline Average & \multirow{4}{*}{$\begin{array}{l}\text { Clay, } \\
\text { Clay } \\
\text { loam }\end{array}$} & & 1.32 & 0.073 & 6.06 & 0.25 & 16.66 & 0.90 & 0.21 \\
\hline Interpretation & & & $\mathrm{L}$ & VL & VL & M & M & $\mathrm{L}$ & $\mathrm{L}$ \\
\hline Range & & $7.7-8.2$ & $\begin{array}{c}0.58- \\
1.98\end{array}$ & $\begin{array}{c}0.03- \\
0.11\end{array}$ & $\begin{array}{l}1.80- \\
13.00\end{array}$ & $\begin{array}{c}0.20- \\
0.39\end{array}$ & $\begin{array}{l}4.1- \\
34.0\end{array}$ & $\begin{array}{c}0.11- \\
1.33\end{array}$ & $\begin{array}{c}0.15- \\
0.26\end{array}$ \\
\hline $\begin{array}{c}\text { Interpre- } \\
\text { tation }\end{array}$ & & $\begin{array}{l}\text { Slightly } \\
\text { Alkaline }\end{array}$ & $\begin{array}{c}\text { Very } \\
\text { Low to } \\
\text { Medium }\end{array}$ & $\begin{array}{l}\text { Very } \\
\text { Low } \\
\text { to } \\
\text { Low }\end{array}$ & $\begin{array}{c}\text { Very Low } \\
\text { to Low }\end{array}$ & $\begin{array}{l}\text { Medium } \\
\text { to High }\end{array}$ & $\begin{array}{c}\text { Very } \\
\text { Low } \\
\text { to } \\
\text { High }\end{array}$ & $\begin{array}{l}\text { Very } \\
\text { Low to } \\
\text { Mediu } \\
\text { m }\end{array}$ & $\begin{array}{l}\text { Very } \\
\text { Low } \\
\text { to } \\
\text { Low }\end{array}$ \\
\hline Critical limit & & & & 0.12 & 10 & 0.12 & 10 & 0.6 & 0.2 \\
\hline
\end{tabular}

Table 1. Initial properties of the soil samples (average of two years)

The unit plot size was $5 \mathrm{~m} \mathrm{X} 4 \mathrm{~m}$. The variety was BARI Dhania 1and seeds were collected from Spices Research Centre, BARI, Faridpur. Coriander seeds were sown in 4 November to 5 December, 2011 and 30 November to 7 December, 2012 providing spacing of row to row $30 \mathrm{~cm}$ and seed to seed $15 \mathrm{~cm}$. Half of nitrogen and whole amount of phosphorus, potassium, sulphur, zinc and boron were applied as basal in the form of urea, TSP, MoP, gypsum, zinc sulphate monohydrate and boric acid, respectively. The remaining nitrogen was top dressed at 30 days after sowing (DAS) of seeds followed by irrigation. Weeding cum thinning was done at 25 and 50 DAS. Mulching was done after irrigation. Sevin powder was sprayed around the plot at initial stage to protect the seeds against ant. Malathion @ $1.5 \mathrm{ml} / \mathrm{L}$ was sprayed against aphid. The spray was done at an interval of 15 days up to 45 days. Harvesting was done when the seeds reached at right stage of maturity. The harvesting was done from 1 to 19 March, 2012 and 18 to 23 March, 2013. Data on yield and yield attributes along with other parameters were collected and subjected to statistical analysis by Least Significant Test (LSD) test. Partial budget and marginal analysis of undominated fertilizer responses on coriander were done following the method suggested by Elias and Karim (1984). 


\section{Results and Discussion}

The result obtained from two years was almost similar in yield and yield attributes and therefore pooled analysis was done.

\section{Plant population}

The effect of applied fertilizer on plant population $\mathrm{m}^{-2}$ of coriander was nonsignificant (Table 2). However, plant population $\mathrm{m}^{-2}$ varied from 79 to 88 . The highest number of plants $\mathrm{m}^{-2}$ (88) was observed in $\mathrm{T}_{4}\left(\mathrm{~T}_{1}+25 \% \mathrm{NK}\right)$ treatment followed by $100 \%$ STB $\left(\mathrm{T}_{1}\right)$ and the lowest $(79)$ in control $\left(\mathrm{T}_{8}\right)$ but this variation was statistically non-significant.

Table 2. Effect of different fertilizer dose on yield and yield contributing characters of coriander (Pooled data of 2011-2012 and 2012-2013)

\begin{tabular}{l|c|c|c|c|c|c}
\hline \multicolumn{1}{c|}{ Treatment } & $\begin{array}{c}\text { Plants m } \\
(\text { no. })\end{array}$ & $\begin{array}{c}\text { Plant } \\
\text { height } \\
(\mathrm{cm})\end{array}$ & $\begin{array}{c}\text { Seeds } \\
\text { plant }^{-1} \\
(\text { no. })\end{array}$ & $\begin{array}{c}\text { 1000 seed } \\
\text { weight }(\mathrm{g})\end{array}$ & $\begin{array}{c}\text { Seed yield } \\
\left(\mathrm{Kg} \mathrm{ha}^{-1}\right)\end{array}$ & $\begin{array}{c}\text { Straw } \\
\text { yield } \\
\left(\mathrm{Kg} \mathrm{ha}^{-1}\right)\end{array}$ \\
\hline $\mathrm{T}_{1}-100 \%$ & 86 & 73.94 & 215 & 4.95 & 1311 & 1613 \\
NPKSZnB (STB) & & & & & & \\
$\mathrm{T}_{2}=\mathrm{T}_{1}+25 \% \mathrm{~N}$ & 85 & 73.44 & 215 & 5.06 & 1342 & 1795 \\
$\mathrm{~T}_{3}=\mathrm{T}_{1}+25 \% \mathrm{NP}$ & 84 & 74.44 & 229 & 5.10 & 1373 & 1877 \\
$\mathrm{~T}_{4}=\mathrm{T}_{1}+25 \% \mathrm{NK}$ & 88 & 73.45 & 216 & 5.06 & 1261 & 1820 \\
$\mathrm{~T}_{5}=\mathrm{T}_{1}+25 \% \mathrm{PK}$ & 81 & 72.80 & 223 & 4.96 & 1263 & 1932 \\
$\mathrm{~T}_{6}=\mathrm{T}_{1}+25 \% \mathrm{NPK}$ & 84 & 74.25 & 222 & 4.93 & 1312 & 1866 \\
$\mathrm{~T}_{7}=75 \%$ of $\mathrm{T}_{1}$ & 84 & 69.80 & 191 & 4.96 & 1137 & 1719 \\
$\mathrm{~T}_{8}=$ Native nutrient & 79 & 54.55 & 111 & 5.15 & 728 & 929 \\
CV(\%) & 12.77 & 8.63 & 10.93 & 6.99 & 11.84 & 11.38 \\
LSD (0.05) & NS & 6 & 40 & NS & 143 & 275 \\
\hline
\end{tabular}

STB $=$ Soil test base $;$ NS $=$ Not significant.

\section{Plant height}

Application of fertilizer significantly influenced the plant height of coriander. But there was no significant variation among the treatments in respect of plant height of coriander (Table 2). However, the plant height among the added fertilizer treatments varied from $69.80-73.44 \mathrm{~cm}$, where all the treatments showed similar except $\mathrm{T}_{8}$ treatment which produced the shortest plant height. The above results showed that fertilizer virtually had no significant effect on the plant height of coriander plant but Oliveira et al. (2003) evaluated that $\mathrm{N}$ fertilizer plays an important role to increase plant height.

\section{Seeds plant ${ }^{-1}$}

The effect of different nutrient combinations was significant on the number of seeds plant ${ }^{-1}$ (Table 2). Fertilizer application increased seeds plant ${ }^{-1}$ from 111 to 
229. Maximum seeds plant ${ }^{-1}$ (229) was observed in $T_{3}\left(T_{1}+25 \% N P\right)$ treatment and it was identical with rest of the treatments except $T_{8}$ treatment. The lowest number of seeds plant ${ }^{-1}$ was obtained from control treatment. The present results are close to the findings of Channabasavanna et al. (2002) who reported that application of $60 \mathrm{~kg} \mathrm{~N} \mathrm{ha}^{-1}+60 \mathrm{~kg} \mathrm{P} \mathrm{ha}^{-1}$ produced the maximum number of seeds plant ${ }^{-1}$.

\section{Thousand seed weight}

There was no significant effect of fertilizer among the treatments in terms of 1000 seed weight of coriander (Table 2). However, the 1000 seed weight among the fertilizer treatments varied from 4.93 to $5.15 \mathrm{~g}$.

\section{Seed Yield}

Seed yield $\mathrm{ha}^{-1}$ was significantly influenced by the application of different fertilizer treatments (Table 2). Fertilizer application increased seed yield from 728 to $1373 \mathrm{~kg} \mathrm{ha}^{-1}$. The maximum seed yield $\left(1373 \mathrm{~kg} \mathrm{ha}^{-1}\right)$ was obtained from the treatment $T_{3}$ due to higher number of seeds plant ${ }^{-1}(229)$ and thousand seed weight $(5.10 \mathrm{~g})$. The experimental soil was deficient in different nutrients. So the application of different nutrients to the soil resulted in the higher uptake by plants which ultimately helped increase production of assimilates that causes higher seeds plant ${ }^{-1}$ and seed size. Response on the yield of coriander to higher doses of fertilizers was observed. Seed yield of coriander was higher when $100 \%$ fertilizer dose was used but yield decreased when $25 \%$ less fertilizer applied. On the other hand, variation in seed yield was found in different combinations of fertilizer treatments (from $\mathrm{T}_{3}$ to $\mathrm{T}_{6}$ ) although it was statistically similar. The maximum yield was observed in $\mathrm{T}_{3}$ treatment where $\mathrm{N}$ and $\mathrm{P}$ combination was used. The treatment of $\mathrm{T}_{4}$ (combination of $\mathrm{NK}$ ) and $\mathrm{T}_{5}$ (combination of $\mathrm{PK}$ ) showed the lower seed yield. Gosh et al. (1986) also reported that yield was greatly influenced by interaction of $\mathrm{N}$ and $\mathrm{P}$ at 60 and $40 \mathrm{~kg} \mathrm{ha}^{-1}$. Channabasavanna (2002) reported that application of $\mathrm{K}_{2} \mathrm{O}$ did not show any beneficial effect on seed yield of coriander. The treatment $\mathrm{T}_{6}\left(\mathrm{~T}_{1}+25 \% \mathrm{NPK}\right)$ also showed the lower yield than treatment $\mathrm{T}_{3}$ due to excess use of $\mathrm{K}$ perhaps which created nutrient imbalance in the soil (soil inherently belongs to medium to high amount of $\mathrm{K}$ (Table 1). The lowest yield $\left(728 \mathrm{Kg} \mathrm{ha}^{-1}\right)$ was obtained from native nutrient $\left(\mathrm{T}_{8}\right)$ where no fertilizer was used.

\section{Stover yield}

The straw yield ha ${ }^{-1}$ varied significantly with different fertilizer treatments (Table 2). The treatment $T_{5}$ produced the maximum straw yield $\left(1932 \mathrm{~kg} \mathrm{ha}^{-1}\right)$, which was statistically similar with all fertilizer added treatments except $T_{1}\left(1613 \mathrm{~kg} \mathrm{ha}^{-1}\right)$. The lowest straw yield $\left(929 \mathrm{~kg} \mathrm{ha}^{-1}\right)$ was obtained from control treatment $\left(\mathrm{T}_{8}\right)$. 


\section{Economic performance}

Gross return was calculated from the price of coriander. Costs that vary were calculated from the cost involved for fertilizer nutrients used for the experimental treatments. The partial budget analysis of fertilizer showed that the highest gross return (Tk. $57922 \mathrm{ha}^{-1}$ ) and gross margin (Tk. $42244 \mathrm{ha}^{-1}$ ) was accounted for $\mathrm{T}_{3}$ treatment because of higher yield though higher cost was involved (Table 3 ). The dominance analysis of various treatments showed that treatments $T_{4}, T_{5}$ and $T_{6}$ were cost dominated due to obtain lower net return against increase of investment (Table 4). Marginal increase in gross margin, marginal increase in cost and marginal rate or return (MRR) of cost undominated treatments were shown in Table 5. The highest MRR $(108 \%)$ was obtained from $T_{1}$ (Soil test based treatment, $100 \%$ NPKSZn) followed by $\mathrm{T}_{7}\left(75 \%\right.$ of $\left.\mathrm{T}_{1}\right)$ treatment. Higher doses of fertilizer treated plots in $\mathrm{T}_{2}$ and $\mathrm{T}_{3}$ provided the highest gross margin but showed lower MRR among the cost undominated treatments and hence, they may not be economic. However, application of only chemical fertilizers at the rate of soil test based treatment $\left(T_{1}\right)$ was appeared at the most suitable treatment for coriander cultivation due to its yield performance $\left(1311 \mathrm{t} \mathrm{ha}^{-1}\right)$, satisfactory gross margin (Tk $41769 \mathrm{ha}^{-1}$ ) and higher marginal rate of return $(108 \%)$. On the contrary, the second highest MRR (79\%) was received from the treatment $\mathrm{T}_{7}$ reduced nutrient cost $33 \%$ than $\mathrm{T}_{1}$ treatment which could be suitable for the poor resource farmers.

Table 3. Cost and return analysis of coriander production as influenced by different fertilizer doses (Pooled data of 2011-2012 and 2012-2013)

\begin{tabular}{l|c|c|c}
\hline \multicolumn{1}{c|}{ Treatment } & $\begin{array}{c}\text { Gross return } \\
\left(\text { Tk. h }^{-1}\right)\end{array}$ & $\begin{array}{c}\text { Nutrient cost } \\
\left(\text { Tk. h }^{-1}\right)\end{array}$ & $\begin{array}{c}\text { Gross margin } \\
\left(\text { Tk. ha }^{-1}\right)\end{array}$ \\
\hline $\mathrm{T}_{1}=100 \%$ NPKSZnB (STB) & 54875 & 13106 & 41769 \\
$\mathrm{~T}_{2}=\mathrm{T}_{1}+25 \% \mathrm{~N}$ & 56355 & 14386 & 41969 \\
$\mathrm{~T}_{3}=\mathrm{T}_{1}+25 \% \mathrm{NP}$ & 57922 & 15678 & 42244 \\
$\mathrm{~T}_{4}=\mathrm{T}_{1}+25 \% \mathrm{NK}$ & 53169 & 13301 & 39868 \\
$\mathrm{~T}_{5}=\mathrm{T}_{1}+25 \% \mathrm{PK}$ & 53434 & 14594 & 38840 \\
$\mathrm{~T}_{6}=\mathrm{T}_{1}+25 \% \mathrm{NPK}$ & 55269 & $\mathbf{1 5 8 7 4}$ & 39395 \\
$\mathrm{~T}_{7}=75 \%$ of $\mathrm{T}_{1}$ & 48069 & 9830 & 38239 \\
$\mathrm{~T}_{8}=$ Native nutrient & 30525 & - & 30525 \\
\hline
\end{tabular}

Price of input (Tk. $\left.\mathrm{kg}^{-1}\right)$ :

Urea: Tk. 20.00, TSP: Tk. 22.00, MoP: Tk. 15.00, Gypsum: Tk 8.00, Boric acid: Tk. 160.00,

Zinc sulphate monohydrate Tk 160.00

Labor Cost (Tk. labor ${ }^{-1}$ ): 300.00

No. of labor required for 1 ha fertilizer application ( 2 times): 3 (2 labor needed for basal application and remaining 1 for top dressing in 1 ha.)

Price of output (Tk. $\mathbf{~ k g}^{-1}$ ): Seed: Tk. 40.00 and Straw: Tk. 1.50 (average of years) 
Table 4. Dominance analysis of various treatments applied in coriander (Pooled data of 2011-2012 and 2012-2013)

\begin{tabular}{lcccc}
\hline \multicolumn{1}{c|}{ Treatments } & $\begin{array}{c}\text { Gross margin } \\
\left(\mathrm{Tk}^{-1} \mathrm{ha}^{-1}\right)\end{array}$ & $\begin{array}{c}\text { Nutrient cost } \\
\left(\mathrm{Tk}^{-1} \mathrm{ha}^{-1}\right.\end{array}$ & Inference \\
\hline $\mathrm{T}_{3}=\mathrm{T}_{1}+25 \% \mathrm{NP}$ & 42244 & 15678 & CUD \\
$\mathrm{T}_{2}=\mathrm{T}_{1}+25 \% \mathrm{~N}$ & 41969 & 14386 & CUD \\
$\mathrm{T}_{1}-100 \%$ NPKSZnB (STB) & 41769 & 13106 & $\mathrm{CUD}$ \\
$\mathrm{T}_{4}=\mathrm{T}_{1}+25 \% \mathrm{NK}$ & 39868 & 13301 & $\mathrm{CD}$ \\
$\mathrm{T}_{6}=\mathrm{T}_{1}+25 \% \mathrm{NPK}$ & 39395 & $\mathbf{1 5 8 7 4}$ & $\mathrm{CD}$ \\
$\mathrm{T}_{5}=\mathrm{T}_{1}+25 \%$ PK & 38840 & 14594 & $\mathrm{CD}$ \\
$\mathrm{T}_{7}=75 \%$ of $\mathrm{T}_{1}$ & 38239 & 9830 & $\mathrm{CUD}$ \\
$\mathrm{T}_{8}=$ Native nutrient & 30525 & 0.00 & CUD \\
\hline
\end{tabular}

CUD: Cost undominated and CD: Cost dominated

Table 5. Marginal analysis of cost undominated treatments applied in coriander at FSRD site, Faridpur (Pooled data of 2011-2012 and 2012-2013)

\begin{tabular}{l|c|c|c|c|c}
\hline $\begin{array}{c}\text { Cost undominated } \\
\text { treatments }\end{array}$ & $\begin{array}{c}\text { Gross } \\
\text { margin } \\
\left(\mathrm{Tk} \mathrm{ha}^{-1}\right)\end{array}$ & $\begin{array}{c}\text { Nutrient } \\
\text { cost } \\
\left(\mathrm{Tk} \mathrm{ha}^{-1}\right)\end{array}$ & $\begin{array}{c}\text { Marginal } \\
\text { increase in } \\
\text { gross margin }^{\left(\mathrm{Tk} \mathrm{ha}^{-1}\right)}\end{array}$ & $\begin{array}{c}\text { Marginal increase } \\
\text { in variable cost of } \\
\text { fertilizer as } \\
\text { nutrient } \\
\left(\mathrm{Tk} \mathrm{ha}^{-1}\right)\end{array}$ & $\begin{array}{c}\text { Marginal } \\
\text { rate of } \\
\text { return }(\%)\end{array}$ \\
\hline $\mathrm{T}_{1}=100 \%$ NPKSZn & 41769 & 13106 & 3530 & 3276 & 108 \\
$(\mathrm{STB})$ & 41969 & 14386 & 200 & 1280 & 16 \\
$\mathrm{~T}_{2}=\mathrm{T}_{1}+25 \% \mathrm{~N}$ & 42244 & 15678 & 275 & 1292 & 21 \\
$\mathrm{~T}_{3}=\mathrm{T}_{1}+25 \% \mathrm{NP}$ & 38239 & 9830 & 7714 & 9830 & 79 \\
$\mathrm{~T}_{7}=75 \%$ of $\mathrm{T}_{1}$ & 30525 & 0 & 30525 & -- & - \\
$\mathrm{T}_{8}=$ Native nutrient & & & & \\
\hline
\end{tabular}

\section{Conclusion}

Two years study revealed that a package of $100 \%$ soil test based dose of chemical fertilizer $\left(\mathrm{N}_{118} \mathrm{P}_{47} \mathrm{~K}_{26} \mathrm{~S}_{10} \mathrm{Zn}_{2.2} \mathrm{~B}_{0.8} \mathrm{Kg} \mathrm{ha}^{-1}\right)$ may be recommended for the cultivation of coriander in low Ganges river flood plain soil for higher yield with economic profitability.

\section{References}

Anonymous, 2011. SAARC Centre. Quality Seed in SAARC countries. Production, processing, legal \& quality control and marketing system. P.112.

Anonymous. 2008. Annual Report for 2007-2008. Spices Research Centre, BARI, Shibganj, Bogra. Pp.104-107. 
Ali, M.M., S.M. Shaeed., D. Kubota., T. Masunaga and T. Wakatsuki. 1997. Soil degeration during the period 1967-1995 in Bangladesh. J. Carbon and nitrogen. Soil Sci. and Plant nutr. 43: 863-878.

Channabasavanna, A. S., S. G. Yalamali and D.P. Biradar. 2002. Nutrient requirment of coriander in Tungabhadra project area of Karnataka. J. MoharastraAgril. Univ. 27(1): 38-39

DAE. 2015. Department of Agricultural Extension. Kreshe Diary 2015. Agriculture Information Service, Khamarbari, Farmgate, Dhaka-1215. P. 15.

Elias,S.M. and Karim M.R. 1984. Application of partial budget technique on cropping system research at Chittagong Division of Agril. Economics, Bangladesh Agril. Res. Institute, Gazipur,Bangladesh. Pp.151-152

Gosh, D., T.K.Maiti., M.G.Som and T.K. Bose. 1986. Effect of row spacing and levels of nitrogen growth and seed yield of coriander. Indian Cocoa Arecanut and Spices Journal, 9(2): 44-46.

Mitra, R.S.K., M.L. Sadhu and T.K. Bose. 1990. Nutrition of Vegetable Crops. Naya prokash, Calcutta, 700006, India. Pp. 157-159.

Oliveira, A.P. de., de S. Paiva-Sobrinho., J.K.A. Barbosa., C.I. Ramalho., A.L.P. Oliveira., A.P. de-Oliveira and S.de. Paiva Sobrinho. 2003. Rendimento de coentro cultivado com doses crescentes de $\mathrm{N}$ (Yield of coriander cultivated with increasing nitrogen levels). Hortic. Bras. 21(1): 81-83.

SAARC Agriculture Centre 2006. Statistical data book for Agriicultural res. \& Dev. in SAARC countries. 2006/07. vol.5, P. 112.

Tripathy, M.L., S.K. Trivedi and R.P. Yadav. 2009. Effect of irrigation and nutrient levels on growth and yield of coriander. Indian J. Agron. 45(4): 25-28 